\title{
The essence of a university and scholarly activity in accounting, with reference to a Department of Accounting at a South African university
}

\author{
DB van der Schyf \\ Department of Accounting \\ University of Pretoria
}

\begin{abstract}
There is increasing academic pressure on Departments of Accounting in South Africa whose academic programmes are accredited with the South African Institute of Chartered Accountants (SAICA). The reason for this that the academic training of potential chartered accountants has long been their main academic focus, and they often fail to do justice to their real academic mission of scholarly activity in accounting (the pursuit of science as an endeavour), which is central to the essence of a university. The quality of such departments' research is not yet an important criterion for their prestige. However, only Departments of Accounting that develop Accounting as a social science in scholarly activity in accounting deserve international recognition. This empirical study attempts to convince Departments of Accounting, particularly those whose academic programmes are accredited by SAICA, to embark on scholarly activity in accounting as soon as possible.
\end{abstract}

\section{Key words}

Accounting as a social science

Accounting theory (conceptual foundations of accounting)

Departments of Accounting (South Africa)

Research process for accounting

SAICA's syllabi

Scholarly activity in accounting

The essence of a university

Theory

\section{Introduction}

The broad aim of this study is to show the growing academic tensions in and pressures on Departments of Accounting (this includes the Auditing, Taxation and Financial Management disciplines) at South African universities over many years, and to suggest solutions that could address these tensions and pressures. In this study, the term, "Departments of Accounting" refers to Departments of Accounting at South African 
universities. The academic training of prospective chartered accountants in South Africa has long been the main academic focus of Departments of Accounting, and these departments have often tended to be fairly casual about their actual academic mission, namely dedicated and full participation in scholarly activity in accounting, in line with the broader quest for knowledge which is unique to the essence of a university (Source: Own observation). The meaning of the phrase "scholarly activity in accounting" relates to the "essence of a university" and is discussed in detail in section 5 of this article.

The term "scholarly activity" is an alternative term for "scholarship". Cryer's (2006:73) view on the meaning of scholarship is: "... [scholarship] - is the body of principles and practices used by scholars to make their claims about the world as valid and trustworthy as possible, and to make them known to the scholarly public. In its broadest sense, scholarship can be taken to include the scientific method, which is the body of scholarly practice that governs the sciences."

Information gleaned from observation and academic experience reveals that the status currently enjoyed by Departments of Accounting in the academic and business community depends largely on whether the South African Institute of Chartered Accountants (SAICA) accredits their academic programmes. It is also common knowledge in South African academic accounting circles that the prestige of such academic departments is further enhanced by the performance of their alumni in Part 1 of SAICA's Qualifying Examination (Source: Own observation). This study focuses on the 14 SAICA-accredited universities (SAICA 2007b) whose undergraduate and graduate programmes are accredited by SAICA and whose syllabi are by implication also accredited by SAICA (2007a).

As far as could be ascertained, the research output of these accredited universities and the quality of such research outputs are not yet regarded as significant criteria for the academic prestige of departments such as the Departments of Accounting, Auditing, Taxation and Financial Management at South African universities.

Gray and McKernan (2000:10) expressed the following opinion about the absence of a research culture in Departments of Accounting at South African universities: “...we see a difficulty facing South African accounting academics ... the research culture at least as understood in the Anglo-Saxon universities - has yet to develop and embed itself." In a recent study comparing the research productivity of South African accountancy academics with those of the Asia-Pacific region, West (2006:121) concluded that "the research outputs of accountancy academics in South Africa seem to lag far behind those of their counterparts abroad".

The aim of this study is to make a logical deduction that the primary task of Departments of Accounting should be in line with the essence of a university. These departments should ensure that Accounting is comprehensively taught and researched in the context of scholarly activity in accounting. This study's particular approach aims to assist Departments of Accounting to embark on scholarly activity in accounting as soon as possible. At this point, it is crucial for the evaluation of this research report to understand that a significant reason for undertaking the study is the creation of a useful, well-founded conceptual research guide for Departments of Accounting, based on Babbie and Mouton's (2001:15) diagram (adapted for the purposes of the study). The diagram is helpful in developing an understanding of scholarly activity in general (with reference 
to accounting) and in explaining the most relevant research concepts in particular. The unique approach followed here is the underlying reason for the apparent deviation from the stereotyped structure. So, for example, in the conceptual approach, the "Problem statement" formulation (it follows after the concept "Problem statement" is properly defined) appears later than usual in the research report as an element of the research process. In this "Introduction" to the research report, the area of research is clearly demarcated and the broad aim of the study is outlined to indicate a possible problem statement.

In the course of their daily activities, academic Departments of Accounting are now faced with the question of whether what they are currently primarily engaged in - the academic training of potential chartered accountants - can be reconciled with the essence of a university and with what their full mandate as academic departments should be.

The risk to South African universities posed by the increasingly dominant dictates of professional councils such as SAICA, which prescribe the content of certain academic programmes, was highlighted as early as the 1970s and 1980s in the Main Report of the Commission of Enquiry into Universities (1974:292), also known as the Van Wyk de Vries Report, and South African Post Secondary Education (SAPSE) Report 108 (SAPSE 1983:64). In broad terms, these reports concur that universities (by implication also Departments of Accounting) should protect themselves against professional councils: "...they will have to guard jealously their fundamentally scientific education mission" (SAPSE 1982b:118).

It is definitely not the intention of this study to adopt a negative approach to the academic training of chartered accountancy candidates at South African universities. However, the purpose of this investigation is to highlight the possible implications of their choices to academic departments that focus primarily on or solely on such training at the expense of scholarly activity in accounting.

This study is primarily argumentative and attempts to make a few recommendations that will hopefully suggest an organised way of thinking about these issues that may assist the Heads of Departments of Accounting (and related disciplines), as well as lecturers, to get their departments on track with regard to scholarly activity in accounting while maintaining their full status as SAICA-accredited departments.

As far as could be ascertained, no similar research has been undertaken in this particular area in South Africa.

\section{Literature review}

In the context of the topic of this article, the literature review conducted for this study was designed to explore the existing relevant scientific subject information and to contextualise the study within the information in that field. According to De Vos, Strydom, Fouché and Delport (2005:117), a literature review should fulfil the following functions:

$\square$ "Demonstrating mastery of the literature in the field

$\square$ Acquainting the reader with existing knowledge on the subject

$\square$ Discussing the proposed study in relation to the current literature

$\square$ Displaying, where relevant, the conceptual and theoretical framework of the study."

Meditari Accountancy Research Vol. 16 No. $12008: 1-26$ 
As mentioned above, no similar research in this particular field could be found. This implies that it is extremely difficult to contextualise this study within existing areas of research; and the literature reviewed below cannot also be linked directly to all four the functions listed above by De Vos et al. (2005).

Nevertheless, there is some relevant literature on the various components of the problem investigated. The first of these components is literature on the essence of a university. Primary data that could be consulted in this regard were international views on the essence of a university, such as Jaspers's (1960:23) arguments. Primary data on the second component of the problem under review, namely scholarly activity in accounting, are also discussed below.

\section{Research process: problem statement, research design and methodology}

The primary aim of this study is to assist Departments of Accounting in South Africa with academic programmes accredited with SAICA to do justice to their real academic mission of scholarly activity in accounting. This is reconcilable with the essence of a university. Two phenomena merit investigation. First, the university as a phenomenon needs to be explored to determine what the primary task of universities in general should be. Secondly, relating to the first point, the main relation between a university or a Department of Accounting and scholarly activity in accounting should be researched.

On the basis of this analysis, appropriate research questions and a number of subquestions were formulated.

Greater insight into the three elements of the research process, namely the problem statement, the research design and the choice of methodology and greater clarification of the formulation of the research problem can be obtained from Babbie and Mouton's (2001:15) diagram below (the diagram has been adapted for the purposes of this study). The diagram also clearly illustrates the link between the research process and scholarly activity in accounting. 


\section{The three world's framework (adapted)}

\begin{tabular}{||l|l|}
\hline \hline * World 3: World of meta-science \\
Paradigms in the philosophy of accounting as a science, for example, accounting as a multiple paradigm science \\
(Riahi-Belkaoui 2004:329), the development of accounting theories using several research methodologies \\
(Schroeder, Clark \& Cathey 2005:102), and the scientific view and accounting (Kam 1990:485), etc. \\
Paradigms in research methodology, for example, quantitative, qualitative and participatory action research
\end{tabular}

Paradigms in research methodology, for example, quantitative, qualitative and participatory action research

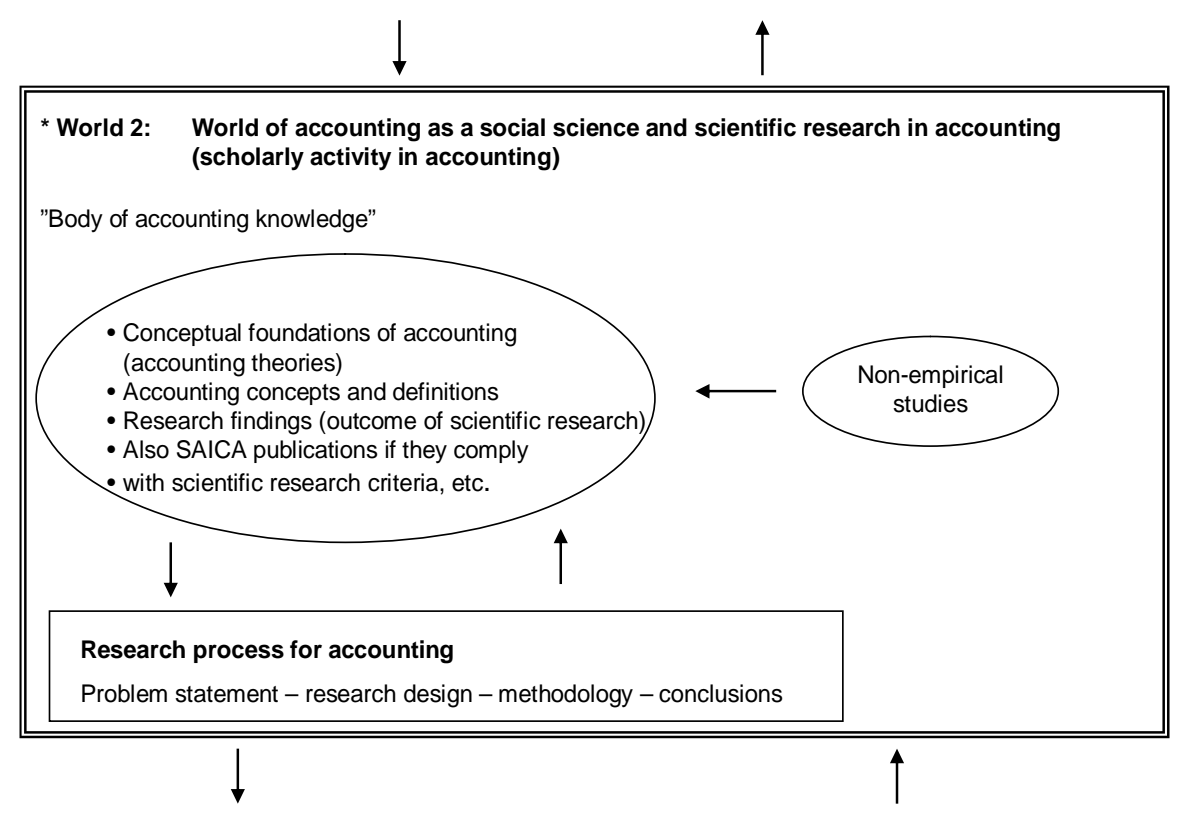

Empirical studies in accounting

\begin{tabular}{l}
\hline * World 1: Everyday life \\
Social/practical problems in accounting (e.g. accounting standards issues, sustainability reporting issues, \\
revisiting the objectives of financial statements and related conceptual issues, etc.) \\
Required interventions/action/programmes/therapy
\end{tabular}

The terms "frame" or "context" can be substituted for the term "world"

World 1 is a representation of the everyday world in which we live, perceive and experience things and perform our daily life tasks (Babbie \& Mouton 2001:15), as well as the world in which professional bodies such as SAICA, with its publications and professional requirements (and parties with any interest in such publications and professional requirements), function on a daily basis. A university with its teaching and research responsibilities operates in World 1 , but in its research capacity it also operates in World 2 and World 3. An Accounting lecturer, for example, with only a teaching responsibility and no research interest, performs in World 1 only and makes no contribution to scholarly activity in accounting. World 1 has accounting research needs that World 2 must meet, in the form of empirical studies conducted scientifically (by using the "body of accounting knowledge" and a scientific "research process for accounting") - see the up and down arrows between World 1 and World 2 . 
In World 2, Accounting academics with their knowledge of World 1 have a research responsibility (unique to the essence of a university). The overriding objective in World 2 is scholarly activity in accounting. Mouton (2001:138) argues that the "search for truth" (scholarly activity) or "truthful knowledge" is the overriding goal of science.

If the research objective in a study tests the plausibility of a new accounting theory and broadens the "body of accounting knowledge" with the assistance of the scientific research process, it is a non-empirical study (operating in World 2 only). Conceptual foundations of accounting (accounting theory) are a crucial component of the "body of accounting knowledge" in the process of scholarly activity in accounting. The topic that probably comes closest to the conceptual foundations of accounting in SAICA's prescribed syllabus is the accounting standard ACOOO "Framework for the Preparation and Presentation of Financial Statements" (conceptual framework) (see pp. 30/05 and 31/05 of the detailed syllabus in the Education requirements of the South African Institute of Chartered Accountants for entry into Part 1 of the Qualifying Examination (SAICA 2005)), issued in October 2005 and available to accredited universities.

Conceptual foundations in accounting in general and various specific approaches to the development of a generally accepted accounting theory are discussed again later in section 5 of this study, particularly in the context of scholarly activity in accounting, or the pursuit of science as an endeavour, together with the fact that accounting is increasingly regarded as a social science.

A last important aspect of World 2 that needs to be briefly examined is the "research process for accounting" and its elements. At the same time, the problem statement, research design and methodology of this study are discussed to illustrate elements of the "research process for accounting".

\section{The research process}

The research process used in World 2 was also used in this study in scholarly activity in accounting. Weirich, Pearson and Reinstein (2005:9) define the research process as follows: "The research process in general is often defined as a scientific method of inquiry, a systematic study of a particular field of knowledge in order to discover scientific facts or principles."

To prevent any possible confusion between the terms "research process" and "research methodology", Brynard and Hanekom (2006:36) provide the following definition of research methodology, which clearly distinguishes it from the research process: "[R]esearch methodology focuses on the process of research and the decisions that the researcher has to take to execute the research project."

The three elements of the research process are discussed individually below.

\section{Problem statement}

The primary research focus of this study is the "essence of a university with reference to scholarly activity in accounting". In order to answer the research question implicit in this research topic, the primary task of a university must first be described accurately. Then, the primary academic tasks of Departments of Accounting at South African universities need to be examined with reference to scholarly activity in accounting. Finally, the study looks at possible factors that may constrain Departments of Accounting at South African universities in performing scholarly activity in accounting properly. 
Formal research questions and possible subquestions can now be formulated as follows with regard to the phenomena under review:

$\square$ Question 1: What is the primary task of a university in the light of the essence of a university?

$\square$ Question 2: In the light of the essence of university - what is the primary task of a Department of Accounting at a South African university with reference to scholarly activity in accounting?

$\square$ Question 3: Which two prominent factors constrain Departments of Accounting at South African universities in performing scholarly activity in accounting properly?

These three questions are answered later in this study under the relevant headings and in the same order as set out above.

Bak (2004:20) comments as follows on the formulation of a research problem in the form of a question: “... formulating your problem in the form of a problem question is fruitful for giving your writing and reading direction - it impels you to answer the question."

In terms of Bak's (2004:21) description, the above research questions are descriptive and analytical. Their empirical nature compels the researcher to gather descriptive information and data from World 1 (e.g. a definition of the essence of a university) and from World 2 (e.g. elements of the "body of accounting knowledge") by using a "scientific method of inquiry" and to draw conclusions and make recommendations with the assistance of the research process (a "scientific method of inquiry").

The remaining two elements of the research process are discussed below.

\section{Research design}

Mouton (2001:55) describes a research design as "a plan or blueprint of how you intend conducting the research". In other words, the research design is the planning element of the research process as it appears in World 2 of the Three Worlds Framework above.

According to Cooper and Schindler (2003:146), there is a link between the research design and the research question: "The design is always based on the research question."

For the purposes of this study, three research designs were drawn up. The purpose of the research designs was to answer each of the three research questions above. The research design also had to provide answers to questions such as which research techniques were used to gather data. Research techniques used in this study include, for example, a literature review, interviews (where possible) and observations.

The approach used to design a study is not always simple and obvious. Cooper and Schindler (2003:102) offer the following advice in this regard: "When more than one way exists to approach the design, discuss the methods you have rejected and why your selected approach is superior." The research design also depends on the type of study being conducted, in other words, whether it is an empirical or a non-empirical study, and whether primary (new) data are used or whether existing or secondary data are analysed (Mouton 2001:57). This study is an empirical study.

Finally, Ryan, Scapens and Theobald (2002:117) emphasise the value of a good research design as follows: "If the researcher has created a 'good' research design, then more valid conclusions and inferences may be drawn from the work."

The research design used in this study was fairly simple and is uniform in the way in which it addresses the three research questions. The research design was not complicated by a complex design strategy, decisions about sampling, the testing or use of 
questionnaires, the revision of questionnaires, and so on. The research design was also the planning element of the research process used in this study. The data, which are mainly primary data, were gathered by means of a literature review. This is an empirical approach. A literature review and observations were the research techniques chosen for this study. They have hopefully ensured that valid conclusions were drawn and deductions could be made on the basis of the research findings.

\section{Methodology}

The terms "research methodology" and "methodology" should not be confused. Methodology is the last essential element of the research process. As indicated earlier, the concept of research methodology focuses on the research process and on the decisions the researcher must make in order to be able to do the research project.

Brynard and Hanekom (2006:36) indicate the meaning of the term "methodology" clearly in the following statement: "In the human sciences, two basic research methods or methodologies can be distinguished: qualitative and quantitative methodology or methodological models."

Mouton (1996:37) represents methodological dimensions as three levels. The first is research techniques (in this study this would be the review of relevant literature, interviews (if possible) and observations). The second is research methods (in this study it would be data collection by means of the research techniques used and the analysis of the data another research method). The third is methodological paradigms (quantitative and qualitative methodologies).

A qualitative methodology is followed in this study in line with the following definition by Henning (2004:5): “... when we refer to 'qualitative research', we are using the term that denotes the type of inquiry in which the qualities, the characteristics or the properties of a phenomenon are examined for better understanding and explanation." In this study, for example, the qualities, characteristics and properties of a university, scholarly activity in accounting to enhance the body of accounting knowledge, and so on, are considered in order to answer the research questions.

For the purposes of this study, the only contributions that were not taken into account were those made in World 3 in the Three Worlds Framework, for example, by subject experts in accounting (such as those who focus on the paradigms in the philosophy of accounting science) and by experts who attempt to enhance and develop research methodology, in so far as it contributes to promoting the body of accounting knowledge or the research process in World 2. Of course, the university as an institution that promotes the pursuit of science as an endeavour is also actively involved in this part of the framework. (In this study, World 3 is not discussed in any more detail.)

The three essential elements of the research process, namely the problem statement, the research design and methodology were discussed individually above, and all three elements are clearly highlighted in the argument in this article.

\section{The essence of a university with reference to South Africa}

The discussion below clearly and scientifically addresses the research question set out above, by means of the research process (see World 2 in the Three Worlds Framework). The research question was formulated earlier under the heading "Problem statement", namely: "What is the primary task of a university in view of the essence of a university?" 
Because of the limitations imposed by the space available for this study, the discussion of the essence of a university is limited to selected local and international views on this topic.

The Merriam-Webster online dictionary (s.a.) defines a university as follows: "[It is] an institution of higher learning providing facilities for teaching and research and authorized to grant academic degrees."

Oxford University (s.a.), the oldest university in the English-speaking world, describes itself "as an internationally renowned centre for teaching and research". Another British university held in high repute, the University of Cambridge (s.a.), states that its mission is "to contribute to society through the pursuit of education, learning, and research at the highest international levels of excellence".

The renowned Harvard Business School, part of the oldest and best-known university in the USA, Harvard University (s.a.), which was founded as Harvard College in 1636, sees its role as follows: "For nearly a century, our faculty have drawn on their passion for teaching, their experience in working with organizations worldwide, and the insights gained from their research to educate generations of leaders who have shaped the practice of business in every industry and in every country around the world."

The view of an educationist, Larkin Kerwin, on the essence of a university was included in The international education quotations encyclopaedia (Noble 1995:240). Larkin Kerwin's view is that "research defines the university. Research is more basic to the university than even teaching, than even public service. Research lies at the university's core."

Jaspers (1960:23) illustrated the primary task of the university in his formulation of the following assumption: "If the university serves science and scholarship and if science and scholarship are meaningful only insofar as they are part of a comprehensive intellectual life, then this intellectual life is the very life blood of the university." Jaspers (1960:59-60) is also a proponent of the notion that university teaching should be aimed at the development of scientifically systematic knowledge and understanding (with reference to the involvement of professional bodies in university training) to enhance the application of the sciences in practice-related situations. In his definition of the objective of university training, he expresses his conviction that it "must provide the professions with a twofold foundation. It must instil a growing lifelong commitment to the scientific outlook, as well as to the search for the unity of knowledge."

Rossouw (2006:2), a South African academic, describes the university and its relationship with professional training by arguing that the university should be an institution that

$\square$ pursues scientific knowledge through learning, teaching and research

$\square$ provides for the need of society for professional training and specialised knowledge and skills

$\square$ preserves knowledge (through publications, seminars and conferences) and facilitates academic discourse within and between disciplines

$\square$ cultivates the intellectual formation of its students and scholars or the cultivation of the philosophical mind

Rossouw (2006:3) is convinced that whenever "the 'cultivation of the philosophical mind' is neglected, disciplines are likely to produce technocrats with knowledge and skills of limited shelf-life". 
Several reports relating to this research topic and the essence of a university were published in South Africa during the 1970s and 1980s. The Main Report of the Commission of Inquiry into Universities (Chairman: J van Wyk de Vries), also known as the Van Wyk de Vries Report, appeared in 1974. The then Department of National Education also published a series of reports, the South African Post-Secondary Education (SAPSE) Reports, which are relevant to the topic discussed in this article. The SAPSE reports, which discussed South African universities, focused on various themes and appeared with the following numbers: 108 (SAPSE 1983); 110 (SAPSE 1982a); 115 (SAPSE 1982b) and 116 (SAPSE 1986). In order to draw suitable conclusions in each of the above reports, the compilers consulted a wide range of relevant literature and research findings, both locally and internationally.

The Van Wyk de Vries Report concluded that the university in South Africa is a corporation, created by an Act of Parliament, is a legal person, with the objectives of practising science at a tertiary level and of being a centre of learning, teaching and education and with the particular authority of conferring degrees (Main Report of the Commission of Inquiry into Universities 1974:73). The report points out that a healthy relationship between universities and professional councils is essential. At that stage, the professional council with an interest in the academic training of prospective chartered accountants was the Public Accountants and Auditor's Board (PAAB) (Main Report of the Commission of Inquiry into Universities 1974:154). Today, the relevant body is SAICA.

Two key findings that reflect concern about the relationship between universities and the professional councils, which are probably still valid today, and of relevance to this study, are quoted from the Van Wyk de Vries Report. Firstly, "professional councils possess powers, granted to them by the various acts, which could place them in a position to exert a strong influence on the universities and even to dictate to them in regard to standards, curricula and syllabuses" (Main Report of the Commission of Inquiry into Universities 1974:163). Secondly, "there would appear to be a possibility that the profession's hold on the universities could result in the overloading of the curricula with training with a practical bias which could turn into purely practical training. This would make it impossible for the universities to fulfil their true function" (Main Report of the Commission of Inquiry into Universities 1974:163).

The risk posed by the increasing and dominant say of professional councils, such as SAICA, in the content of academic programmes offered by Departments of Accounting is still present. Such an influence can make it extremely difficult for a department to fully pursue science as an endeavour.

In the various SAPSE reports, as in the Van Wyk de Vries Report, concern is raised about the increasingly dominant dictates of professional councils such as SAICA with regard to the universities' academic programmes. In broad terms, these reports agree that universities must protect themselves against professional councils: “... they will have to guard jealously their fundamentally scientific education mission” (SAPSE 1982b:118).

It is nevertheless interesting that the two professional councils of the accounting profession of that time, namely the National Council of Chartered Accountants (SA) and the Public Accountants' and Auditors' Board (PAAB) (1980:126), in their joint report, The Report of the Commission of Enquiry into Developments in the Accountancy Profession in South Africa, also expressed their concern about lecturers' research contributions at universities, the programmes of which were registered with the PAAB as follows: "In the 
two decades, 1951 to 1971, the universities provided adequate technical education but achieved very little in developing accounting as an academic discipline."

An analysis and interpretation of the above views in the literature, which was widely consulted, on the essence of a university show that there is a fair amount of consensus that the university's primary task is that of research to contribute to scholarly activity. This answers the first research question.

With regard to the above, the question can now be asked whether the Departments of Accounting at South African universities with academic programmes that are accredited by SAICA are active role players in scholarly activity in accounting, in line with the essence of a university. As indicated above, in their studies, Gray and McKernan (2000:10) and West (2006:121) found that this was not the case. Gray and McKernan (2000:10) commented that "the research culture ... has yet to develop and embed itself". West (2006:121) summarised the situation fittingly in his finding that "the research outputs of accountancy academics in South Africa seem to lag far behind those of their counterparts abroad".

The next question is what the primary task of a Department of Accounting at a South African university is with reference to scholarly activity in accounting. This question is discussed in the next section.

\section{The primary task of a Department of Accounting at a South African university with reference to scholarly activity in accounting}

It is again necessary to note that universities in their task of pursuing science as an endeavour are supposed to be active role players in Worlds 1, 2 and 3. It falls beyond the scope of this study to discuss universities' research role in World 3, the world of metascience. Instead, the focus of the discussion in this section of this article is the interaction between World 1 ("Everyday life") and World 2 ("The World of Accounting as a social science and scientific research in accounting", scholarly activity in accounting).

The main elements of the body of accounting knowledge (with reference to World 2) are the conceptual foundations of accounting (accounting theory), accounting concepts and definitions and research findings. These are also the components of accounting as a social science that need to be developed with the assistance of the scientific research process in accounting. The conceptual foundations of accounting are the element of the body of accounting knowledge that many Departments of Accounting in South Africa tend to neglect. This is obvious from research publications over nearly two decades in the South African Journal of Accounting Research (SAJAR) (see http://www.sajar.co.za), Meditari (see http://www.meditari.org.za) and master's dissertations and doctoral theses in accounting completed at some universities (Source: Own observation). Accounting concepts and definitions are attended to because they are largely incorporated in the accounting standard AC000 Framework for the Preparation and Presentation of Financial Statements and are taught to students. This element does receive some attention in Departments of Accounting, but not in the context of scholarly activity (Source: Own observation). Research findings, the outcomes of scientific research, can be found in journals that publish accounting research, both nationally and internationally. There is some concern, however, that it is not part of the academic culture of Departments of Accounting in South Africa to assess research findings in the context of accounting as a social science 
and accounting theory in scholarly activity. Hence accounting as a social science and accounting theory, are discussed briefly below, under their own subheadings, with reference to scholarly activity.

\subsection{Accounting as a social science}

Before accounting as a social science is examined more closely, it would be appropriate to look at the meaning of the word "science".

According to The International Education Quotations Encyclopaedia (Noble 1995:252), J.H. Poincare comments on the meaning of the word "science" as follows: "Science is facts. Just as houses are made of stones so is science made of facts. But a pile of stones is not a house and a collection of facts is not necessarily science." Similarly, A.F. Chalmers, in his book What is this thing called science says the following: "If observation of the world is carried out in a careful, unprejudiced way then the facts established in this way will constitute a secure, objective basis for science" (Chalmers 1999:1).

Mouton's (2001:138) view of the meaning of the term "science" relates directly to what scientific research in accounting should be (as set out in World 2, in The Three Worlds Framework). He posits that the search for truth or truthful knowledge is the overriding goal of science. The question that arises is whether accounting is a science.

The internationally renowned accounting academic, Robert Sterling, expressed the following opinion on this question in his well-known 1979 book, Toward a science of accounting: "Nothing about our subject matter requires accounting to be an art instead of a science" (Sterling 1979:12). He goes further in stating the following criterion for accounting to be regarded as a fully fledged social science: "[it needs to] ... adopt the general scientific criteria of empirical testability and relevance. That is the first step and the most important step toward a science of accounting (Sterling 1979:218). According to Hendriksen and Van Breda (1992:21), "accounting as a science [is] still in [a] primitive stage". Wolk, Dodd and Tearney (2004:39) argue that "we can expect accounting, along with economics and other social sciences, to be less precise in its measurements and predictions than the natural sciences".

Riahi-Belkaoui (2004:322) is convinced that "accounting is a full-fledged social science". He cites the following definition of science by Buzzell: "[Science is] ... a classified and systematized body of knowledge organized around one or more central theories and a number of general principles ... usually expressed in quantitative terms ... knowledge which permits the prediction and, under some circumstances, the control of future events" (Riahi-Belkaoui 2004:348). Riahi-Belkaoui (2004:348) then concludes that accounting "meets the above criteria. It has a distinct subject matter and includes underlying uniformities and regularities conducive to empirical relationships, authoritative generalizations, concepts, principle, laws and theories. It definitely can be considered a science."

On the basis of the above discussion and authoritative views in the literature, it can be concluded that accounting is a social science and deserves the status of a full-fledged social science in the university context. Departments of Accounting at South African universities must therefore face the challenge of developing accounting as a social science by conducting scientific research - scholarly activity in accounting. Ultimately, meeting the challenge of conducting such discipline-related research is what a university expects from all its academic disciplines. 
This then partially answers research question 2 formulated in section 3 for section 5 . What remains to be discussed is accounting theory as part of the body of accounting knowledge with reference to scholarly activity.

\subsection{Accounting theory with reference to scholarly activity in accounting}

In the discussion of accounting theory below, the value of accounting theory is first briefly explored and then various approaches to the formulation of accounting theory briefly examined. (Although accounting theory construction is obviously an important related topic, a discussion of it falls beyond the scope of this study)

Accounting theory is a central element of the body of accounting knowledge (see World 2 in the Three Worlds Framework) and is vital in scholarly activity in accounting (the development of accounting as a social science).

Mouton (1996:173) clearly summarises the relationship between scientific research and theory as follows: "It is generally accepted that scientific research does not take place in a vacuum ... Given the importance of the argumentative context of scientific research, ... one or more theoretical views should be integrated with the logic of the research objective or task."

It is precisely in this area where accounting research in South Africa may be said to be lacking, largely because there is considerable ignorance about accounting theory. This is noticeable in the accounting research publications that have been published over the years in the only two relevant accredited specialist journals, namely the South African Journal of Accounting Research and Meditari. (A follow-up study may wish to analyse research published in the two journals to discover whether they can be regarded as sufficiently scientific in scholarly activity in accounting. Completed master's dissertations and doctoral theses in accounting could also be included here.)

By contrast, the situation in most developed countries looks different. The professional body of the Certified Public Accountants (CPA), the American Institute of Certified Public Accountants (AICPA), the equivalent professional body to SAICA, "promotes research in accounting theory and has published a series of Accounting Research Monographs and has also issued four conceptual statements (Weirich et al. 2005:60)".

According to Gray and McKernan (2000:10), "few [accountants] use accounting theory as opposed to ad hoc reasoning - to explain whether a balance sheet makes any sense ..."

Deegan and Unerman (2006:4) are strongly convinced of the value of a thorough knowledge of accounting theory: "Given that accounting theories aim to provide a coherent and systematic framework for investigating, understanding and/or developing various accounting practices, the evaluation of individual accounting practices is likely to be more effective where the person evaluating these practices has a thorough grasp of accounting theory." They also point out the dangers that arise in a teaching situation where students only learn "how to apply various accounting practices without questioning the basis of these practices". According to Deegan and Unerman (2006:4), the accounting profession has recently been heavily criticised worldwide for its lack of a "theoretically informed understanding" of accounting. They argue that "in the wake of a growing number of highprofile accounting failures (such as Enron and WorldCom in the USA, Ahold in the Netherlands, Parmalat in Italy, Shell in the Netherlands and the UK, and Addeco in 
Switzerland), it has never been more important for accountants to thoroughly understand and be able to critique the accounting practices which they use".

Finally, according to Riahi-Belkaoui (2004:210), the value of accounting theory lies in its ability to make it possible for accounting specialists to meet the following criterion: "A full appreciation of the current and future scope of accounting depends, however, on an understanding not only of accounting techniques but also of the structure of accounting theory from which the techniques are derived."

The above discussion has sufficiently highlighted the value of accounting theory.

The following simple perspective on the usefulness of theory is striking and should stimulate interest in the concept, particularly in the overwhelmingly pragmatic accounting environment: "Theory without practice is empty, and practice without theory is blind." This opinion was expressed by J.R. Kidd, and is included in The international education quotations encyclopaedia (Noble 1995:300).

To be considered truly scientific, according to the National Association of Sciences (1998), a theory must

$\square$ be consistent with the observational and experimental evidence

$\square$ be able to make accurate predictions

$\square$ be logical and respect the rules of evidence

$\square$ give a public reporting of its methods and procedures

$\square$ be open to criticism and revision

Hendriksen and Van Breda's (1992:22) definition of accounting theory, which complies in broad terms with the criteria of a truly scientific theory, as defined by the National Association of Sciences (1998) cited above, is as follows:

"Accounting theory has been defined as a coherent set of logical principles that:

1 Provides a better understanding of existing practices to practitioners, investors, managers and students.

2 Provides a conceptual framework for evaluating existing accounting practices.

3 Guides the development of new practices and procedures."

Before discussing accounting theory in more detail, it is appropriate to remind ourselves of the South African situation. According to Hendriksen and Van Breda's (1992:22) definition (above), accounting theory provides, inter alia, "a conceptual framework for evaluating existing accounting practices". Chartered accountancy candidates in South Africa are largely exposed to this component of accounting theory when they encounter the accounting statement ACOOO Framework for the preparation and presentation of financial statements. If the lecturer teaching ACOOO does not take the opportunity to emphasise the integral relationship between an accounting statement and accounting theory, the lecturer passes up an ideal chance of exposing students to the body of accounting knowledge and ignores a facet of the pursuit of science as an endeavour.

For a full discussion of standard setting and theory formulation, readers are referred to Thomas G. Evans's (2003:4-190) book, Accounting theory: contemporary accounting issues.

The status of accounting statement ACOOO may dampen lecturers' enthusiasm in presenting the statement. The statement does not override any formal accounting standards; 
it does not have the same authority as an International Financial Reporting Standard (IFRS) - "where there is a conflict between the framework and a specific Standard the Standard will always prevail" (Vorster, Koornhof, Oberholster \& Koppeschaar 2006:12). Wolk et al. (2004:3) emphasise the following relation between accounting theory and accounting standards: "We interpret the definition of accounting theory broadly. Clearly the drafting of a conceptual framework that is supposed to provide underlying guidance for making of accounting rules falls within the coverage of accounting theory." The following comment by Riahi-Belkaoui (2004:ix) also explains the origins of the conceptual framework: "A single generally accepted accounting theory does not exist at this time. Several attempts have been made to formulate such a theory. Starting with different assumptions and using different methodologies, the various attempts have resulted in different frameworks for financial reporting standards." Riahi-Belkaoui (2004:ix) adds the following important comment on accounting standards: "[T]he standard setting process must be guided by a generally accepted accounting theory." In the absence of a generally accepted accounting theory, according to Schroeder et al. (2005:63), the role of the conceptual framework is to "attempt to develop concepts useful to guide [practitioners] in establishing accounting standards and in providing a frame of reference for resolving accounting issues".

For a long time, in the accounting literature, there have been attempts to formulate a generally accepted accounting theory. William R. Scott (2006:5) claims that in 1966 in the American Accounting Association's (AAA) monograph, A Statement of Basic Accounting Theory (also known as $A S O B A T$ ), the concept "decision-usefulness" was included in an accounting publication for the first time. Scott (2006:5) also argues that "[c]urrent statements of basic accounting principles, most notably the Conceptual Framework ... are based on decision-usefulness". He (2005:15) adds that "decision theory underlies the Conceptual Framework". Another attempt to establish a generally accepted accounting theory was made by the Committee on Concepts and Standards for External Financial Reports, which published a report entitled Statement on Accounting Theory and Theory Acceptance commissioned by the American Accounting Association (AAA). In this report, the committee drew the following conclusion (AAA 1977:1-2):

$\square$ "no single governing theory of financial accounting is rich enough to encompass the full range of user-environment specifications effectively; hence,

$\square$ what is found in the financial accounting literature is not a theory of financial accounting but a collection of theories which can be arrayed over the differences in user-environment specifications".

As pointed out earlier, thus far there is no generally accepted accounting theory. The various approaches to the formulation of an accounting theory are briefly discussed below. Hendriksen and Van Breda (1992:19) provide a schematic representation of theories (in general) that also depict the basic points of departure for theories (see table 1).

Table 1 Schematic representation of theories in general

\begin{tabular}{|c|c|}
\hline \multicolumn{2}{|c|}{$\begin{array}{l}\text { Theory } \\
\text { Descriptive or prescriptive (positive vs. normative) }\end{array}$} \\
\hline $\begin{array}{l}\text { Reasoning } \\
1 \text { Deduction (Is it logically sound?) } \\
2 \text { Induction (What evidence is there?) }\end{array}$ & $\begin{array}{ll}\text { Language } \\
1 & \text { Syntactics (What are the rules?) } \\
2 & \text { Semantics (What does it mean?) } \\
3 & \text { Pragmatics (What effect will it have?) }\end{array}$ \\
\hline
\end{tabular}

Source: Hendriksen \& Van Breda (1992:19) 
Theories can be classified as descriptive or prescriptive, in other words, as descriptive (positive) accounting theory or as prescriptive (normative) accounting theory. According to Riahi-Belkaoui (2004:109), a methodology must be used to formulate an accounting theory. A descriptive methodology attempts to justify accounting practices that are regarded as useful, while a normative methodology attempts to justify accounting practices that ought to be adopted. According to Wolk et al. (2004:31), positive accounting research "attempts to explain behavioral relationships in accounting. It attempts to describe 'what is', without making any value judgements as [to] how things should be...". Godfrey, Hodgson and Holmes (2003:9) claim that dissatisfaction with normative theories centres on the fact that they "cannot be empirically tested because it is impossible to demonstrate empirically what ought to be". That makes positive theory more attractive. According to Deegan and Unerman (2006:10), a conceptual framework is an example of a normative theory of accounting. In this case, normative accounting theory is based on the various assumptions that are made about the types of attributes of information that are useful for decision making.

Vorster (2007:33) contends that a "conceptual framework constitutes merely (a part of) the body of accounting theory, normative theory. There is also a huge body of positive and inductive theories to be found in accounting literature. Together they constitute the body of accounting theory."

A conceptual framework provides guidance, inter alia, on how assets, liabilities, expenses, revenues and equity should be defined.

In the above brief discussion, an overview was presented of the meaning, in the accounting context, of the concepts and theories regarding a descriptive approach (and related positive accounting theory) and prescriptive (and related normative accounting theory), as set out in the schematic representation of the theories above. Next, the concepts of language and reasoning referred to in the schematic representation are briefly discussed, again in an accounting context.

Hendriksen and Van Breda (1992:14) claim that accounting is a business language. Consequently, there are three questions that accounting as a business language should answer, namely:

What effect will the words have on listeners? (pragmatic theories)

$\square$ What meaning, if any, do the words have? (semantic theories)

$\square$ Do the words make logical sense? (syntactic theories)

Each of these theories can be seen in the development of accounting theories and is briefly defined below. Schroeder et al. (2005:102) believe that the pragmatic (descriptive) approach to the development of accounting theory is based on the concept of utility or usefulness. Riahi-Belkaoui (2004) holds a similar view, in that he claims that, in terms of a pragmatic approach, accounting techniques and principles should be chosen on the basis of their usefulness to the users of accounting information and their relevance to the decisionmaking process. Semantic theories, like syntactic theories, are by nature descriptive, but, unlike syntactic theories, they have an empirical content (Hendriksen \& Van Breda 1992:19). These theories attempt to say something about the real world; their truth depends upon observation. Syntactic theories are by nature descriptive, have no empirical content and are confirmed by the logic of rules. So, for example, if the percentage of gross profit on sales is $30 \%$ and an article is sold for R1 000.00, it is logical that the gross profit is 
R300.00. Many accounting propositions fall into this category, and are true for syntactic reasons.

With regard to the concept of reasoning in the schematic representation above, deductive or inductive reasoning can be used to formulate an accounting theory. Both deductive and inductive theories can be descriptive (positive) or prescriptive (normative). The deductive approach to the formulation of an accounting theory moves from theory to practice, and from the general to the specific. Riahi-Belkaoui (2004:111) lists the following steps that should be followed in the deductive approach:

$\square$ Step 1: Specifying the objectives of financial statements

$\square$ Step 2: Selecting the postulates of accounting

$\square$ Step 3: Deriving the principles of accounting

$\square$ Step 4: Developing the techniques of accounting.

Kam (1990:42) defines the term "postulates" as the basic assumptions of accounting. The going concern assumption is an apt example of this.

According to Riahi-Belkaoui (2004:112), an inductive approach to the development of an accounting theory "begins with observations and measurements and moves toward generalized conclusions", and the inductive approach to the formulation of an accounting theory consists of the following stages (Riahi-Belkaoui 2004:112):

$\square$ Stage 1: Recording all observations

$\square$ Stage 2: Analysing and classifying these observations to detect recurring relationships (likes and similarities);

$\square$ Stage 3: Inductively deriving generalisations and principles of accounting from observations that depict recurring relationships

$\square$ Stage 4: Testing the generalisations

In addition to the deductive and inductive approaches to the formulation of an accounting theory, there are other well-known approaches. Riahi-Belkaoui (2004:110-116) lists some of these other options:

$\square$ an ethical approach - the basic core of the ethical approach consists of the concepts of fairness, justice, equity, and truth

$\square$ a sociological approach - this approach emphasises the social effects of accounting techniques

$\square$ an economic approach - this approach emphasises controlling the behaviour of macroeconomic indicators that result from the adoption of various accounting techniques

$\square$ the eclectic approach - this approach is the result of numerous attempts by individuals and professional organisations to participate in the establishment of concepts and principles in accounting

The eclectic approach has given rise to the following new approaches: a regulatory approach, behavioural approaches and the event, predictive and positive approaches.

To conclude this discussion of the various possible approaches to formulating an accounting theory, it is important to recall Riahi-Belkaoui's (2004:116) advice: "Whatever approach is chosen, it is important to remember that an accounting theory must be confirmed to be accepted." In his opinion, the verification of a theory can also be the 
objective of research (Riahi-Belkaoui 2004:107): “...theory should be subject to a logical or empirical testing to verify its accuracy".

Hendriksen and Van Breda (1992:22) comment as follows on the value of the different approaches: "Each of the several approaches to accounting theory has some merit in helping to establish and evaluate accounting principles and procedures."

In respect of the above discussion, it is necessary to bear in mind that accounting theory is developed and refined by the process of accounting research. It is part of scholarly activity in accounting. In this process, the body of accounting knowledge, which includes accounting theory, is expanded. Departments of Accounting not only have a responsibility to develop and refine accounting theory, but must also ensure that, where appropriate in any research, appropriate scientific acknowledgment and consideration are accorded to the relevant approach to accounting theory. This forms part of the full-fledged pursuit of science as an endeavour.

Finally, in respect of the above, in the interests of accounting research in South Africa, it is appropriate to repeat Mouton's (1996:173) view on the relation between scientific research and theory: "It is generally accepted that scientific research does not take place in a vacuum ... Given the importance of the argumentative context of scientific research ... one or more theoretical views should be integrated with the logic of the research objective or task."

The above discussion emphasises the primary task of Departments of Accounting at South African universities and appropriately answers research question 2 in section 3 . Next, in answering research question 3 formulated in section 3 above, the article looks at possible factors that might constrain Departments of Accounting at South African universities in performing their expected mission, namely to participate properly in scholarly activity in accounting.

\section{Factors that may constrain South African Departments of Accounting in their scholarly activity in accounting}

\subsection{Historical disadvantage: the first factor}

The historical development of some South African Departments of Accounting goes back as far as 1918. Four of these long-established Departments of Accounting were randomly selected to demonstrate that from the outset, a research culture has been absent in these departments. The four universities are the University of Kwa-Zulu Natal, Stellenbosch University, the University of Cape Town and the University of Pretoria. These four universities are all SAICA-accredited universities and academically highly respected, particularly for the sustained sound performance of their alumni in Part 1 of SAICA's Qualifying Examination.

The history of the Department of Accounting at the University of Kwa-Zulu Natal (UKZN - previously the University of Natal) was recorded fairly comprehensively by Maguire (1980:219-227), a former lecturer in the Department. According to Maguire (1980:219), Accounting was presented at the university for the first time in 1919 and the first Head of Department was appointed in 1941. In 1951, this department, like many other Departments of Accounting, instituted the Certificate in the Theory of Accountancy. This qualification gave access to the Final Qualifying Examination of the PAAB (Maguire 
1980:103). Consequently, the academic training of prospective chartered accountants took several years. Maguire does not mention any research achievements of the Department. However, he does indicate that the Department was at some stage known for the conceptual approach that it followed in its teaching of the introductory accounting course (Maguire 1980:223).

Stellenbosch University (SU) offered Bookkeeping (Afrikaans: Boekhou) for the first time in 1924. In 1925, Mr B.J.A. Thomas was appointed as a Senior Lecturer in Bookkeeping and Accounting Science (Afrikaans: Rekeningwetenskap) (Fakulteit van Handelswetenskappe, 1942:15). Mr G.J. Vosloo was appointed as a lecturer in Accounting Science from 1945 and continued his accounting practice. It can also be assumed that $\mathrm{Mr}$ C.A. Smith, later Professor and Head of Department, was already a lecturer in the Department of Accounting by 1948, because he appears in a photograph in a commemorative publication edited by Marais (1948:25). Although research activity is mentioned with regard to Economics and Business Management, inter alia, in the earlier years, nothing is said about research activity in Accounting. Similar to other well-known universities, the focus of the Head of Stellenbosch University's Department of Accounting from 1951 onwards was the academic training of prospective chartered accountants; and research only began to receive attention much later. Research publications by lecturers from Stellenbosch University in SAJAR and Meditari over the years confirm this contention.

The website of the Department of Accounting at the University of Cape Town states that the Department was established in 1921 (University of Cape Town s.a.). In e-mail correspondence, the Head of Department confirmed that the Department's history was not formally recorded. It can be assumed, particularly on the basis of the low degree of involvement by lecturers at that university in publications in SAJAR and Meditari over the years, that research was low on the list of the Department's priorities, as was the case at UKZN and SU, from the inception of the Department (Source: Own observation).

According to the historical publication, Ad Destinatum II (1960-1982) (University of Pretoria 1982:132-133), which records the history of the University of Pretoria until 1982, Accounting was instituted at that university in 1918 as a subject for a diploma course, at the request of the Transvaal Society of Accountants. In 1919, it was included as a subject in the new BCom degree. On 1 April 1924, the Department of Accounting was created and its first Head of Department appointed (University of Pretoria 1960:193). In 1951, the academic training of prospective chartered accountants began, and in 1953, the first students registered for the new BCom (Accounting Sciences) degree which, together with the degree MCom (Accounting Sciences), gave access to the admission examination of the PAAB (Ad Destinatum (1908-1960) 1960:190). Although it is clear from the two editions of Ad Destinatum, Ad Destinatum (1908-1960) and Ad Destinatum II (1960-1982), that research was a serious academic aspiration for most departments at the university, nothing is said about research activity in the Department of Accounting. It can therefore be assumed that the academic training of accountants in general, and later prospective chartered accountants in particular, was the main academic focus, as it was at all the other South African universities under discussion.

From the above discussion, it can be deduced that, from their inception, almost all the most prominent Departments of Accounting at South African universities were dedicated overwhelmingly to the academic training of prospective chartered accountants. By allowing a professional body, formerly the PAAB and currently SAICA, to prescribe the syllabus 
contents of some academic programmes, the Departments of Accounting have, probably out of ignorance, created a historical backlog in fulfilling their obligations in scholarly activity in accounting, in the university context. The historical background of the Departments of Accounting in the field of research, as confirmed above, is supported by the finding of The Report of the Commission of Inquiry into Developments in the Accountancy Profession in South Africa that in "the two decades, 1951 to 1971, ... [Departments of Accounting] achieved very little in developing accounting as an academic discipline" (National Council of Chartered Accountants \& PAAB 1980:126).

Next, another factor that may constrain South African Departments of Accounting in their endeavours in scholarly activity in accounting is discussed.

\subsection{The content of SAICA'S syllabus: the second factor}

In the discussions in sections 4 and 5 above, it was concluded that Departments of Accounting, as part of the academic world of the university, have an academic responsibility to develop and refine accounting theory and, where appropriate, to give suitable recognition, inter alia, to relevant approaches to accounting theory in their scientific research. This is part of scholarly activity in accounting, or the pursuit of science as an endeavour.

The historical research backlog that was mentioned briefly above is a significant factor that continues to constrain Departments of Accounting in South Africa in their aspirations to scholarly activity in accounting. In order to fully answer the research question set out above, another factor, namely SAICA's syllabus content and its consequences, also needs to be briefly discussed.

For much too long, the main focus has been the academic training of prospective chartered accountants. If SAICA's syllabi are analysed, it is clear that students are not exposed to the conceptual foundations of accounting (accounting theory) and research methodology. The main source referred to in this regard was the following publication made available to accredited universities by SAICA (2005): The Education Requirements of the South African Institute of Chartered Accountants for entry into Part 1 of the Qualifying Examination, issued in October 2005.

Topics in SAICA's syllabi that come closest to the topic of "conceptual foundations of accounting" (although there are still vast differences) are the following (SAICA 2005:30/05):

"Candidates should be able to do the following:

- Identify the objectives of financial statements"

[Comments:

(a) An opportunity to link this topic to the first step in the deductive approach to formulating an accounting theory is not exploited.

(b) Assessments introduced by the verb "identify" are on the second-lowest level of Bloom's Taxonomy. This is extremely low on the taxonomy and suggests that the topic is not accorded much importance. Bloom identified six levels in the cognitive domain (Bloom's Taxonomy s.a.).]

- "Explain the need for and the application of a conceptual framework and for standards for financial reporting." 
[Comments:

(a) First, the following remark by Wolk et al. (2004:3) is appropriate here with regard to the conceptual framework: "Clearly the drafting of a conceptual framework that is supposed to provide underlying guidance for making accounting rules falls within the coverage of accounting theory." Second, according to Deegan and Unerman (2003:9), a conceptual framework is an example of a normative theory of accounting. Third, with reference to standards for financial reporting, the following relationship between the conceptual framework and accounting theory can also be exploited here: “... the standard setting process must be guided by a generally accepted accounting theory" (Riahi-Belkaoui 2004:ix). An ideal opportunity to connect the prescribed topic with accounting theory is also missed here.

(b) Again the assessment terms are on the second-lowest level of Bloom's Taxonomy. This is extremely low on the taxonomy and suggests that the topic is not accorded much importance.]

- "Explain and apply the underlying assumptions on the basis of which financial statements are prepared."

[Comments:

(a) This topic presents an opportunity to connect the topic with accounting theory in general and deductive theory in particular. Working with assumptions or postulates is the second step in developing a deductive approach to formulating an accounting theory. This opportunity in the SAICA syllabus to give candidates exposure to accounting theory should be used.

(b) Assessment - the verb "explain" is also on second-lowest level of Bloom's Taxonomy. Again this is extremely low, and suggests that the topic is not accorded much importance in the evaluation of the candidates' skills, etc.]

Although research methodology per se is not pertinently stated to be an area of knowledge required for Part 1 of the Qualifying Examination anywhere in the publication, under " 1.7 Examination Policy" (SAICA 2005:14/03), there is a reference to Standard 3 and Standard 6 of the International Federation of Accountants' (IFAC's) International Education Standards for Professional Accountants (IFAC 2003:54), without any comment suggesting exposure to "research" (IFAC 2003:48) or "logical and analytical thinking, powers of reasoning, and critical analysis ...”. (skills that can be acquired by exposure to the conceptual foundations of accounting). The latter two groups of skills are indicated in the IFAC's document entitled International Education Standards for Professional Accountants as elements of intellectual skills that belong among the Professional Skills for Professional Accountants (IFAC 2003:54). The standards concerned came into force on 1 January 2005. Member organisations of IFAC, such as SAICA, are expected to implement the standards (IFAC 2003:2), although the following statement on the authority of the document needs to be looked at: "Although these Standards cannot override authoritative local pronouncements, they are prescriptive in nature" (IFAC 2003:3). SAICA will have to consider implementing IFAC's stipulations in this regard in the immediate future. Universities should also strongly support this initiative.

According to the requirements for bachelor's honours degree programmes set out in the Higher Education Qualifications Framework Act, such academic programmes must include 
"conducting and reporting research under supervision". Exposure to the conceptual foundations of accounting is implied in the following expectations regarding a bachelor's honours degree: "[It] demands a high level of theoretical engagement and intellectual independence" (Department of Education 2007:25)

From the above discussion, particularly regarding SAICA's syllabus content, it is clear that one can state without fear of contradiction that the syllabi content for the academic training of potential chartered accountants is not in the best interests of scholarly activity in accounting.

In this part of the article, a number of significant factors that constrain the ability of Departments of Accounting at South African universities to search properly for truthful knowledge (scholarly activity) in accounting were highlighted.

This implies that research question 3 formulated in section 3 of the article has been appropriately answered.

\section{Conclusions and recommendations}

The primary aim of this study, as stated at the start of this article, was to reveal the increasing academic tension that has arisen in Departments of Accounting (including the Auditing, Taxation and Financial Management disciplines) at South African universities over many years. The reason for this is the fact that the academic training of prospective chartered accountants has long been the main academic focus in such departments, while they have failed to do justice to their actual academic mission, namely scholarly activity in accounting, in line with the essence of a university. This academic tension was confirmed in the findings of this article and several suggestions were made to resolve this problem.

The Three Worlds Framework was used to illustrate the interaction between research activities in World $\mathbf{1}$ and World 2. It was shown that phenomena in World $\mathbf{1}$ are investigated in empirical studies with the assistance of the body of accounting knowledge and a particular appropriate research process. This is scholarly activity in accounting. In this way accounting is developed as a social science.

In the above discussion, the three main elements of the research process, namely the problem statement, the research design and methodology were explained and applied.

The essence of a university was discussed from an international and national perspective, and it was concluded that the primary task of a university is scholarly activity. Furthermore, it was concluded that the university is an active research role player in World 1, World 2 and World 3. (Owing to the limitations of the scope of this article, the role of World 3 was not discussed here.)

It was found that Departments of Accounting have a vital academic responsibility in the university context, namely scholarly activity in accounting. In this regard, thorough knowledge of the conceptual foundations of accounting (also known as accounting theory) and research methodology play a key role as part of accounting as a social science.

It was also found that at South African universities, from as far back as 1918, compared to other academic disciplines, accounting has had a historical backlog in terms of its pursuit of science. Another factor that has constrained the pursuit of science in accounting, particularly since 1951, was the continued dominant focus in Departments of Accounting at 
South African universities on the academic training of prospective chartered accountants at the expense of scholarly activity in accounting.

SAICA's syllabus was critically evaluated. The study concluded that the current syllabi cannot be reconciled with the scholarly activity in accounting. However, it was shown that SAICA can in fact support Departments of Accounting in scholarly activity in accounting, provided that the disciplines of Research Methodology and the Conceptual Foundations of Accounting are included the SAICA syllabi. Knowledge of the latter discipline is also essential for accounting practitioners. The inclusion of these two disciplines in SAICA's syllabi would also be in line with IFAC's education standards. It should be possible for SAICA and Departments of Accounting to continue to work together, but both parties will have to make a number of adjustments to produce alumni who can become chartered accountants and who are better equipped academically to face challenges of business practice.

A few examples of topics for possible follow-up research that is strongly recommended include the following:

$\square$ the current status of departments of Accounting at (SAICA-accredited) universities perspectives held by academics and the business community (including accounting practitioners)

$\square$ compulsory academic exposure to the conceptual foundations of accounting (accounting theory) - the value thereof for accounting academics in South Africa

$\square$ compulsory academic exposure of prospective chartered accountants to research methodology and the conceptual foundations of accounting (accounting theory) and an evaluation of the advantages of such exposure for the accounting practice.

\section{Bibliography}

American Accounting Association (AAA). Committee on Concepts and Standards for External Financial Reports. 1977. Statement on accounting theory and theory acceptance. Sarasota, Fla: American Accounting Association.

Babbie, E. \& Mouton, J. 2001. The practice of social research. Cape Town: Oxford University Press.

Bak, N. 2004. Completing your thesis: a practical guide. Pretoria: Van Schaik.

Bloom's Taxonomy. s.a. http://www.officeport.com/edu/blooms.htm. Accessed: March 2007.

Brynard, P.A. \& Hanekom, S.X. 2006. Introduction to research in management-related fields. $2^{\text {nd }}$ edition. Pretoria: Van Schaik.

Chalmers, A.F. 1999. What is this thing called science? $3^{\text {rd }}$ edition. Indianapolis, Ind: Hackett.

Cooper, D.R. \& Schindler, P.S. 2003. Business research methods. $8^{\text {th }}$ edition. New York: McGraw-Hill/Irwin.

Cryer, P. 2006. The research student's guide to success. Berkshire: Open University Press.

Deegan, C. \& Unerman, J. 2006. Financial accounting theory. European edition. Berkshire, UK: McGraw-Hill. 
Department of Education. 2007. The Higher Education Qualifications Framework Act. Pretoria: Government Printer.

De Vos, A.S., Strydom, H., Fouché, C.B. \& Delport, C.S.L. 2005. Research at grassroots for the social sciences and human service professions. $3^{\text {rd }}$ edition. Pretoria: Van Schaik.

Duderstadt, J.J. 2000. A university for the $21^{\text {st }}$ century. Ann Arbor, Mich: University of Michigan Press.

Evans, T.G. 2003. Accounting theory: contemporary accounting issues. Mason, Ohio: Thomson South Western.

Fakulteit van Handelswetenskappe, Universiteit van Stellenbosch [Faculty of Commercial Sciences, Stellenbosch University]. 1942. Stellenbosch: ProEcclesia.

Godfrey, J., Hodgson, A. \& Holmes, S. 2003. Accounting theory. $5^{\text {th }}$ edition. Milton, Queensland, Australia: Wiley.

Gray, R. \& McKernan, J. 2000. Accounting education: crisis? What crisis? Accountancy and Finance Update, 5(2):9-11.

Harvard University. S.a. http://www.president.harvard.edu/history/. Accessed: February 2007.

Harvard Business School. S.a. http://www.hbs.edu/aboutindex.html. Accessed: February 2007.

Henning, E. 2004. Finding your way in qualitative research. Pretoria: Van Schaik.

Hendriksen, E.S. \& Van Breda, M.F. 1992. Accounting theory. $5^{\text {th }}$ edition. Homewood Ill: Irwin.

International Federation of Accountants (IFAC). 2003. International education standards for professional accountants. New York: IFAC.

Jaspers, K. 1960. The idea of the university. London: Peter Owen.

Kam, V. 1990. Accounting theory. $2^{\text {nd }}$ edition. New York: Wiley.

Koornhof, C. 2004. Balancing general and professional education in the economic, financial and management sciences. University of Pretoria: Inaugural address.

Maguire, W.A.A. 1980. Strategy for Departments of Accounting of South African universities. Master's dissertation, Pretoria, University of South Africa.

Main Report of the Commission of Inquiry into Universities. 1974. Pretoria: Government Printer.

Marais, W.T. 1948. "Vooruitgang 1948; Uitgawe ter herdenking van die 25-jarige bestaan van die Fakulteit van Handelswetenskappe van die Universiteit van Stellenbosch en by die geleentheid van die inwyding van die nuwe gebou vir Sosiale Wetenskappe".[Progress 1948; edition to commemorate 25 years of the Faculty of Commercial Sciences at the University of Stellenbosch and the occasion of the opening of the new Social Sciences building.] Stellenbosch University.

Merriam-Webster online dictionary. S.a. www.merriam-webster.com/dictionary/ university. Accessed: February 2007.

Mouton, J. 2001. How to succeed in your master's and doctoral studies. Pretoria: Van Schaik.

Mouton, J. 1996. Understanding social research. Pretoria: Van Schaik. 
National Association of Sciences. 1998.http://www.bigbend.edu/soc/tcas/theory. htm. Accessed: March 2007.

The National Council of Chartered Accountants and the Public Accountants' and Auditors' Board (PAAB). 1980. The Report of the Commission of Enquiry into Developments in the Accountancy Profession in South Africa. Johannesburg.

Noble, K.A. 1995. The international education quotations encyclopaedia. Buckingham: Open University Press.

Oxford University. S.a. http://www.ox.ac.uk/aboutoxford/. Accessed: February 2007.

Riahi-Belkaoui, A. 2004. Accounting theory. London: Thomson Learning.

Rossouw, G.J. 2006. Philosophy and the university: trends and temptations. University of Pretoria: Inaugural address.

Ryan, B., Scapens, R.W. \& Theobald, M. 2002. Research method and methodology in finance \& accounting. $2^{\text {nd }}$ edition. London: Thomson Learning.

SAICA. 2005. The Education Requirements of the South African Institute of Chartered Accountants for entry into Part 1 of the Qualifying Examination. October 2005. Johannesburg: SAICA.

SAICA, 2007a. https://www.saica.co.za/DisplayContent.asp?ContentpageID401. Accessed: February 2007.

SAICA, 2007b. https://www.saica.co.za/documents/List_ofaccredited_programmes_ education06.pdf. Accessed: February 2007.

Schroeder, R.G., Clark, M.W. \& Cathey, J.M. 2005. Financial accounting theory and analysis. $8^{\text {th }}$ edition. Hoboken, NJ: Wiley.

Scott, W.R. 2006. Financial accounting theory. $4^{\text {th }}$ edition. Toronto: Pearson Prentice-Hall.

South African Post Secondary Education (SAPSE). 1982a. SAPSE-110. Investigation of government financing of universities. Pretoria: Department of National Education.

South African Post Secondary Education (SAPSE). 1982b. SAPSE-115. The qualifications and study programmes of universities in South Africa. Pretoria: Department of National Education.

South African Post Secondary Education(SAPSE). 1983. SAPSE-108. The objectives, structure and operation of Post Secondary Education System. Pretoria: Department of National Education.

South African Post Secondary Education (SAPSE). 1986. SAPSE-116. Qualification structure for universities in South Africa. Pretoria: Department of National Education.

Sterling, R.R. 1979. Toward a science of accounting. Houston, Tex: Scholars Book Company.

University of Cambridge. S.a. http://www.admin.cam.ac.uk/univ/mission.html. Accessed: February 2007.

University of Cape Town, S.a. http://www.uct.ac.za/faculties/commerce/departments/ accounting/. Accessed: October 2007.

University of Pretoria. 1960. Ad Destinatum (1908-1960). Pretoria: University of Pretoria.

Vorster, Q. 2007. The conceptual framework, accounting principles and what we believe is true. Accountancy SA, June:30-33. 
Vorster, Q., Koornhof, C. Oberholster, J.G.I. \& Koppeschaar, Z.R. 2006. Descriptive accounting. $11^{\text {th }}$ edition. Durban: LexisNexis Butterworths.

Weirich, T.R., Pearson, T.C. \& Reinstein, A. 2005. Accounting and auditing research. $6^{\text {th }}$ edition. Mason, Ohio: Thomson South Western.

West, A. 2006. A commentary on the global position of South African accounting research. Meditari Accountancy Research, 14(1):121-137.

Wolk, H.I., Dodd, J.L. \& Tearney, M.G. 2004. Accounting theory: conceptual lissues in a political and economic environment. $6^{\text {th }}$ edition. Mason, Ohio: Thomson South Western. 